\title{
Economic Value of Ecosystem Restoration in Biscayne Bay, Florida1
}

\section{Donna J. Lee and Anafrida Bwenge ${ }^{2}$}

Information for this EDIS publication is based on Chapter 7 in Land Management Impacts on Coastal Watershed Hydrology, Progress in Water Resources Series, A. Fares and A.El-Kadi, eds., WIT Press, Ashurst, UK. The full text version can be accessed at http://invasive.ifas.ufl.edu.

\section{Acknowledgments}

Thanks for help from the following scientists: Gary R. Milano from the Department of Environmental Resources and Management, Miami-Dade County; Doria R. Gordon of The Nature Conservancy and Department of Botany at the University of Florida; and Alan Hodges from the Food and Resource Economics Department in the College of Agriculture and Life Sciences in the Institute of Food and Agricultural Sciences at the University of Florida.

\section{Executive Summary}

The United States' natural ecosystems have been invaded by approximately 5,000 exotic plant species which compete with 17,000 native plant species for space and resources. The total cost, including damages and control expenditures of invasive plants in natural systems, has been estimated to be $\$ 159.5$ million (Pimentel, 2002). In Florida, the establishment of exotic plants in natural ecosystems has jeopardized the viability of many listed threatened and endangered species. State response has been public funding for controlling invasive plants in natural areas at $\$ 32$ million per year. This study examined the value of restoring ecosystems compromised by exotic plants in Biscayne Bay, Florida. Since 1987, more than $\$ 11$ million has been spent on exotic plant removal and coastal habitat restoration in Biscayne Bay. Results show a net gain from restoring coastal ecosystems in Biscayne Bay, Florida of $\$ 41$ million, with an internal rate of return of $11 \%$.

\section{Cost of Invasive Plants in the United States}

U.S. natural ecosystems have been invaded by approximately 5,000 exotic plant species which compete with 17,000 native plant species for space and resources. Many of the invaders were brought to the United States to be grown for food, feed, fiber, and ornamental purposes. While most non-indigenous species are unable to survive in the wild, some

1. This is EDIS document FE662, a publication of the Food and Resource Economics Department, Florida Cooperative Extension Service, Institute of Food and Agricultural Sciences, University of Florida, Gainesville, FL. Published August 2006. Please visit the EDIS website at http://edis.ifas.ufl.edu.

2. Donna J. Lee, Associate Professor, and Anafrida Bwenge, Graduate Research Assistant, Food and Resource Economics Department, Florida Cooperative Extension Service, Institute of Food and Agricultural Sciences, University of Florida, Gainesville, FL.

The Institute of Food and Agricultural Sciences (IFAS) is an Equal Opportunity Institution authorized to provide research, educational information and other services only to individuals and institutions that function with non-discrimination with respect to race, creed, color, religion, age, disability, sex, sexual orientation, marital status, national origin, political opinions or affiliations. U.S. Department of Agriculture, Cooperative Extension Service, University of Florida, IFAS, Florida A. \& M. University Cooperative Extension Program, and Boards of County Commissioners Cooperating. Larry Arrington, Dean 
possess characteristics that enable them to grow and reproduce rapidly, unchecked by natural enemies, and out-compete native plants for space, sunlight, and nutrients. Often growing in monocultures, invasive plants diminish biodiversity, alter habitats, and eliminate natural food sources for native birds, reptiles, and mammals. In February 1999, former President Bill Clinton signed an executive order allocating \$28 million to combat invasive species (Pimentel, 2000).

Invasive plants are responsible for $\$ 24$ billion in damages to U.S. food and horticultural crops each year (Pimentel, 2002). The U.S. food and horticulture industries each spend upwards of $\$ 9.5$ billion controlling invasive plants. To control just a few of the plants invading natural systems (e.g., Purple loosestrife, Melaleuca, and invasive aquatics), expenditures top $\$ 104$ million each year. The total cost, including damages and control expenditures, of invasive plants in the agriculture and horticulture sectors is $\$ 34.5$ billion. The total cost, including damages and control expenditures of invasive plants in natural systems, is at least $\$ 159.5$ million (Pimentel, 2002).

In Florida, exotic plants are common and numerous. In the past century, over 1,300 exotic plant species have become established in the State; 124 species are destructive to natural areas and have been classified by the Florida Exotic Plant Pest Council as Category I and Category II invasive species (FLEPPC, 2006). Because of their habitat-destroying proclivity, invasive plants jeopardize the viability of many listed endangered species in Florida.

Private expenditure in Florida for controlling invasive plants in the agriculture and forest industries is \$265 million per year (Lee, 2005). State expenditure for prevention and control of invasive plants is \$103 million per year (FLDEP, 2006). Public funding to control invasive plants in natural areas is $\$ 32$ million per year, with $\$ 6.3$ million for upland invasive plants and $\$ 25.7$ million for freshwater aquatic invasive plants (FLDEP, 2004; FLDEP, 2005).

\section{Restoring Biscayne Bay's Ecosystems}

Biscayne Bay, Florida is a 428-square-mile (1,109-square-kilometer) subtropical estuarine ecosystem which formed 3,000 to 5,000 years ago when the sea level rose and flooded the natural limestone depression that is now south Florida. The bay supports a diverse flora and fauna, and serves as a nursery for coral reef and marine ecosystems (USGS, 2006). The unique environment of Biscayne Bay is home to 31 animal species that have been listed as endangered, threatened, or "of special concern". Seven species listed as endangered by both the State and Federal governments are as follows: American crocodile, Atlantic green turtle, Atlantic hawksbill turtle, Cape Sable seaside sparrow, Wood stork, Florida panther, and West Indian manatee (Cantillo et al., 2000).

Throughout the last century, rapid population growth, urbanization, and development of the Miami-Dade County area have altered the Bay environment. Extensive dredging in the early 1900s reshaped the Bay and created navigation channels-notably the Atlantic Intra-coastal Waterway (ICW). Remnants of ICW construction are a series of large spoil-fill islands which have become popular recreational sites. Unstable shorelines, human activity, and overgrowth of exotic vegetation contribute to island erosion and Biscayne Bay turbidity (Wanless et al., 1984; Milano, 2000).

To preserve and protect the natural setting, Biscayne National Monument was established in 1968 for the "education, inspiration, recreation, and enjoyment of present and future generations a rare combination of terrestrial, marine, and amphibious life in a tropical setting of great natural beauty" according to Public Law 90-606. In 1980, the monument was enlarged and held the distinction as the largest marine park in the National Park System (USGS, 2006) for 26 years until June 2006 when President George Bush named the Northwestern Hawaiian Islands a marine reserve and national monument.

Uninhibited growth of exotic vegetation, loss of bird and marine habitats, and eroding shorelines 
prompted a major coastal wetland restoration effort in Biscayne Bay (Milano, 1999). The Biscayne Bay Restoration and Enhancement Program coordinates activities such as removal of exotic vegetation, excavation of emplaced spoil fill, planting of native vegetation, stabilization of eroding shorelines, and long-term success monitoring. In addition, a significant component of the program is the restoration and reestablishment of natural ecosystems to create suitable and stable habitats for native birds, fish, and mammals (Milano 2000). Between 1987 and 2000, \$11 million was spent on ecosystem restoration and enhancement in Biscayne Bay. Work comprised 10 large-scale wetland projects and 12 island projects. Today those expenditures have a present value cost of \$16 million.

\section{Assessing the Benefits from Restoring Biscayne Bay}

Methods such as hedonic price, travel cost, and random utility models use information from market-traded goods to infer environmental values indirectly. Property value method and marginal productivity method are other means of utilizing available market data to indirectly ascertain environmental service values. The contingent valuation method obtains values directly by querying subjects regarding their willingness to pay for environmental services. The benefits transfer method draws on findings from previous valuation studies in one locale to make inferences about the environmental values in another locale. Benefits transfer is the method applied in this study.

Milon (2002) estimated the value of the Indian River Lagoon, a coastal estuary located in South Florida. Milon applied the property value method, marginal productivity method, contingent valuation method, and the travel cost method. Based on property values, human uses (including fishing, swimming, boating, nature watching, water sports, and hunting), passive uses, and commercial shell fishing, Milon estimated an ecosystem value for the Indian River Lagoon. Costanza et al. (1997) compiled findings from a myriad of studies to provide a reference on the values for a wide range of ecosystem types and the services they provide. This approach would be classified as benefits transfer. The team of authors categorized 11 aggregate ecosystem types and defined 17 classes of services. Among the aggregate ecosystems types were coastal estuaries and coastal wetlands (categorized as tidal marsh and mangroves). Among their 17 service classes, we chose three: "recreation", "food production", and "cultural" to capture Direct Human Use Value. We allocated the remaining service classes (e.g., "disturbance regulation", "nutrient cycling", and "'habitat") to the broad category Indirect and Non-use Values. Ecosystem benefit values from Milon (2002) and Constanza et al. (1997), adjusted to 2006 dollars, appear in Table 1, with values applied to Biscayne Bay projects. The estimated value of the services gained from restoring Biscayne Bay ecosystems appears in Table 2.

\section{Findings}

Invasive plants in natural areas are notorious for their ability to change ecosystems. In Florida coastal areas, invasive species have replaced native plants, dislodged native animals, and radically altered hydrologic processes such as tidal flows, dune replacement, and shoreline erosion rates. This study applied the benefits transfer method to assess the value of restoring damaged ecosystems in Biscayne Bay, Florida. Annual benefit when the systems are fully restored is estimated to be $\$ 1.7$ million. Long-term value of these restored ecosystems is $\$ 57$ million. The cost of the projects was $\$ 16$ million in 2006 dollars. Thus the net benefit from the restoration projects is estimated to be $\$ 41$ million. The internal rate of return from restoration expenditures is $11 \%$.

\section{References}

Cantillo, A.Y., K. Hale, E. Collins, L. Pikula, and R. Caballero. 2000. Biscayne Bay: Environmental History and Annotated Bibliography. Technical Memorandum NOS NCCOS CCMA 145. National Oceanic and Atmospheric Administration, Department of Commerce, Washington, D.C.

Costanza, R., R. d'Arge, R deGroot, S. Farber, M. Grasso, B. Hannon, K. Limburg, S. Naeem, RV O'Neill, J. Paruelo, R.G. Raskin, P. Sutton, and M. van den Belt. 1997. The Value of the World's 
Ecosystem Services and Natural Capital. Nature 387(15):283-260.

FLDEP. 2006. Florida Department of Environmental Protection, Bureau of Invasive Plant Management Website. http://www.dep.state.fl.us/lands/invaspec/2ndlevpgs/ Research.htm.

FLDEP. 2005. Status of the Aquatic Plant Maintenance Program in Florida Public Waters. FLDEP Annual Report FY 2003-4. Florida Department of Environmental Protection, Bureau of Invasive Plant Management, Tallahassee, FL.

FLDEP. 2004. Upland Invasive Exotic Plant Management Program, FLDEP Annual Report FY 2002-3. Florida Department of Environmental Protection, Bureau of Invasive Plant Management, Tallahassee, FL.

FLEPPC. 2006. List of Florida's Invasive Species. Florida Exotic Plant Pest Council Website. http://www.fleppc.org.

Lee, D.J. 2005. The Private Cost of Upland Invasive Plants in Florida. Florida's Invasive Species Working Group Website, Institute of Food and Agricultural Sciences, University of Florida, Gainesville, FL. http://www.iswgfla.org.

Milon, J.W. 2002. Natural Resource Valuation of Indian River Lagoon, Chapter 8, Florida Coastal Environmental Resources: A Guide to Economic Valuation and Impact Analysis, edited by D. Letson and J.W. Milon. Gainesville, FL: Florida Sea Grant (SGR-124).

Milano, G.R. 1999. Restoration of Coastal Wetlands in Southeastern Florida. Wetland Journal 11(2):15-24.

Milano, G.R. 2000. Island Restoration and Enhancement in Biscayne Bay. Proceedings of the 26th Annual Conference on Ecosystem Restoration and Creation, edited by P.J. Cannizarro, 1-17. Hillsborough Community College, Tampa, FL.

Pimentel, D. 2002. Biological Invasions. Boca Raton, FL: CRC Press.
Pimentel, D., L. Larch, R. Zuniga, and D. Morrison. 2000. Environmental and Economic Costs of Non-indigenous Species in the United States. BioScience 50(1):53-65.

USGS. 2006. South Florida Ecosystem History Project. U.S. Geological Survey website http://sofia.usgs.gov/flaecohist/biscaynebay.html.

Wanless, H.R., D. Cottrell, R. Parkinson, and E. Burton. 1984. Sources and Circulation of Turbidity, Biscayne Bay FL. Final report to Florida Sea Grant College Program, University of Florida, Gainesville, FL, and Dade County, Miami, FL. 
Economic Value of Ecosystem Restoration in Biscayne Bay, Florida

Table 1. Value of coastal ecosystem services applied to Biscayne Bay restoration.

\begin{tabular}{|c|c|c|c|c|}
\hline Ecosystem Services & Shore & Coastal & Dune & Mangrove \\
\hline & \multicolumn{4}{|c|}{ dollars per acre, per year } \\
\hline Indirect and Non-use & $\$ 326$ & $\$ 12,622$ & $\$ 5,016$ & $\$ 5,016$ \\
\hline Direct Human Use & $\$ 0$ & $\$ 748$ & $\$ 747$ & $\$ 747$ \\
\hline All Services & $\$ 326$ & $\$ 13,370$ & $\$ 5,763$ & $\$ 5,763$ \\
\hline Description & $\begin{array}{l}\text { Construction } \\
\text { activities to stabilize } \\
\text { shoreline and reduce } \\
\text { erosion }\end{array}$ & $\begin{array}{l}\text { Restore native } \\
\text { vegetation to create } \\
\text { and enhance coastal } \\
\text { strand and maritime } \\
\text { hammock ecosystem }\end{array}$ & $\begin{array}{l}\text { Restore native } \\
\text { vegetation to create } \\
\text { and enhance dune } \\
\text { ecosystem }\end{array}$ & $\begin{array}{l}\text { Restore native } \\
\text { vegetation to create } \\
\text { and enhance } \\
\text { mangrove and fresh } \\
\text { wetland ecosystem }\end{array}$ \\
\hline
\end{tabular}

Table 2. Ecosystem services benefits worksheet summary.

\begin{tabular}{|lccc|}
\hline \hline & \multicolumn{3}{c|}{ Ecosystem Services Values } \\
\hline & Indirect and Non-use & Direct Human Use & All \\
\cline { 2 - 4 } Wetland Ecosystems & $\$ 820,440$ & dollars per year & \\
Island Ecosystems & $\$ 711,411$ & $\$ 121,983$ & $\$ 942,422$ \\
& & $\$ 58,957$ & $\$ 770,368$ \\
\hline \hline
\end{tabular}

